\title{
Effect of Crops and Cropping Systems on Sulphur and Micronutrient Availability of Geo Referenced Soils of Ramanathapuram District in Tamil Nadu, India
}

\author{
Aswathy S. Nair*, S. Thyigeshwari and D. Muthumanickam \\ Department of Soil Science and agricultural chemistry, Tamil Nadu Agricultural University \\ (TNAU), Coimbatore, Tamil Nadu, India \\ *Corresponding author
}

\section{A B S T R A C T}

\section{Keywords \\ DTPA - extractable micronutrients, sulphur, soil physical and chemical properties, cropping system \\ Article Info \\ Accepted: \\ 23 September 2017 \\ Available Online: \\ 10 October 2017}

The DTPA extractable cationic micronutrients, sulphur and some important soil physico-chemical properties were investigated in two cropping system of Ramanathapuram district of Tamil Nadu using GPS technique. Considering the critical limits of soil micronutrients, all soil associations were not adequately supplied with DTPA extractable micronutrients in rainfed chillies and rice cropping systems. Irrespective of cropping systems, the DTPA extractable cationic micronutrients were positively related with organic carbon content and negatively related to calcium carbonate content. Deficient soil samples were found in both cropping systems.

\section{Introduction}

Micronutrients deficiencies are often noticed in the soils under intensive cropping system of many agriculturally progressive states in India. The imbalanced use of fertilizer nutrients, increased demand of high yielding varieties, intensive cropping, decrease in recycling of organic manures and micronutrient free high input agricultural activities leads to continuous mining of micronutrients in soils leading to declined crop productivity and soil heath. The deficiency may either be primarily due to their low contents or secondarily by soil factor that reduce the availability (Sharma and
Chaudhary, 2007). The extent of micronutrient deficiency varies not only in different states and districts but also in different blocks within the district. Micronutrient deficiencies are the one of the main causes for low yield or crop yield decline in irrigated (Katyal and Rattan, 2003) and rainfed cropping system in agriculture (Rego et al., 2007). On the basis of computation of exhaustion period of micronutrient reserve under different cropping system soil zinc is the most limiting micronutrients followed by copper (Rattan et al., 2009). Besides soil characteristics, land 
use pattern also plays a vital role in governing the nutrient dynamics and fertility of soils (Venkatesh et al., 2003). Assessing and mapping the fertility status of soils precisely using GPS techniques provides a great opportunity to plan for sustaining the productivity of crops and improving the economy of the country. Hence, the study was conducted to assess the micronutrient availability of soils in Ramanathapuram district of Tamil Nadu in different cropping system. Basic details on the system of cultivation, crops cultivated and cropping system followed in the study area were also collected to understand the relationship between soil nutrient availability and management strategies adopted. The relationship between soil physicochemical properties and available micronutrients status was worked out by constructing correlation studies to know the major factor that governs the nutrient availability. Due to continuous cultivation, soils under a particular land use system may affect physico-chemical properties which may modify DTPA extractable micronutrients content and their availability to crops. So, analysis of these properties along with micronutrient status of different land use systems may have significant importance. Scanty information is available on status of cationic micronutrients and sulphur under different cropping system in the Ramanathapuram district of Tamil Nadu. An attempt has, therefore, been made to generate information regarding the DTPAextractable $\mathrm{Fe}, \mathrm{Zn}, \mathrm{Mn}, \mathrm{Cu}$ and sulphur status under two dominant cropping system, viz. rainfed rice and chillies of Ramanathapuram district of Tamil Nadu using GPS.

\section{Materials and Methods}

One hundred and eighty three samples were collected from rainfed rice growing areas of Ramanathapuram district in eleven blocks. Two hundred and twenty four samples were collected from rainfed chillies growing areas of Ramanathapuram district. The surface geo referenced soil samples were processed and analysed for $\mathrm{pH}$, organic carbon, $\mathrm{CEC}$, and available nitrogen, phosphorus and potassium following standard methods. The DTPA extractable $\mathrm{Fe}, \mathrm{Zn}, \mathrm{Mn}$ and $\mathrm{Cu}$ were extracted with di-ethylene tri- amine penta-acetic acid (DTPA) solution (Lindsay and Norwell 1978) and subsequently analysed with the help of atomic absorption spectrophotometer (Chemito-203)

\section{Results and Discussion}

The $\mathrm{pH}$, electrical conductivity, organic carbon status of the rainfed rice growing soils in different blocks of Ramanathapuram district ranged from 6.78 to $8.74,0.10$ to 0.42 $\mathrm{dS} \mathrm{m} \mathrm{m}^{-1}$ and 0.14 to 0.42 per cent with mean of $7.96,0.23 \mathrm{dS} \mathrm{m}^{-1}$ and 0.25 per cent. The free $\mathrm{CaCO}_{3}$ values varied from 0.94 to 12.54 per cent with a mean of 8.74 per cent (Table 1) indicating that the soils were non to slightly calcareous in nature. Among the blocks, the part of the soils of from all the blocks were moderately calcareous in nature except Mandabam block.

The available sulphur content in the rainfed rice growing soils of Ramanathapuram district ranged from 6.82 to 51.81 with a mean of $22.99 \mathrm{mg} \mathrm{kg}^{-1}$ indicating high in soil available sulphur status. The highest mean soil available sulphur content noticed in Mandabam (39.26 mg kg-1) and the lowest in Kamudiblock (12.28 $\mathrm{mg} \mathrm{kg}^{-1}$ ).

The DTPA-extractable $\mathrm{Zn}$ status of the soils ranged from deficient too high in availability (0.12 to 6.22) with a mean of $0.75 \mathrm{mg} \mathrm{kg}^{-1}$ (Table 2). All the block mean values of $\mathrm{Zn}$ were deficient in Ramanathapuram district except Rajasingamangalam block. The available $\mathrm{Fe}$ content in rainfed rice soils ranged from 3.51 to $43.54 \mathrm{mg} \mathrm{kg}^{-1}$ with a 
mean of $13.75 \mathrm{mg} \mathrm{kg}^{-1}$ (Table 2). The average mean values indicated that, rainfed rice soils of all the blocks were found sufficient in DTPA-Fe status except Mandabam (4.95) and Kadaladi blocks (7.16). The soil samples of Rajasingamangalam block registered the highest mean available Fe status (19.72 mg $\mathrm{kg}^{-1}$ ) under the rainfed system of rice cultivation.

Deficient to sufficient $\mathrm{Cu}$ status (0.15 to 3.81 $\mathrm{mg} \mathrm{kg}^{-1}$ ) with a mean of $1.27 \mathrm{mg} \mathrm{kg}^{-1}$ noticed in rainfed rice soils (Table 2). The average mean $\mathrm{Cu}$ status of the blocks revealed that, almost all the blocks were sufficient in $\mathrm{Cu}$ status except in Rajasingamangalam, Tirupullani, Mudukulathur, Kadaladi, Thiruvadanai and Mandapam blocks.
The DTPA-Mn content in rainfed rice growing soils of Ramanathapuram district ranged from 1.52 to $48.56 \mathrm{mg} \mathrm{kg}^{-1}$ with a mean of $11.74 \mathrm{mg} \mathrm{kg}^{-1}$ indicating sufficient in availability of Mn in all the blocks (Table 2).

The highest DTPA-Mn availability was noticed in all block soil samples under the rainfed system of rice cultivation.

The $\mathrm{pH}$ of the rainfed chillies growing soils in different blocks of Ramanathapuram district ranged from 6.74 to 8.14 with a mean of 7.93 . The electrical conductivity (EC) of the soils varied from 0.04 to $0.63 \mathrm{dS} \mathrm{m}^{-1}$ with a mean of $0.23 \mathrm{dS} \mathrm{m}^{-1}$ indicating that the soils are low in salt concentration. (Table 3)

Table.1 Soil properties of rainfed rice growing soils in different blocks of

Ramanathapuram district $(\mathrm{n}=183)$

\begin{tabular}{|c|c|c|c|c|c|c|c|c|c|c|}
\hline \multirow[t]{2}{*}{$\begin{array}{l}\text { S. } \\
\text { No }\end{array}$} & \multirow[t]{2}{*}{ Name of the block } & \multirow[t]{2}{*}{$\begin{array}{c}\text { No. of } \\
\text { Samples }\end{array}$} & \multicolumn{2}{|c|}{$\mathrm{pH}$} & \multicolumn{2}{|c|}{$\mathrm{EC}(\mathrm{ds} / \mathrm{m})$} & \multicolumn{2}{|c|}{$\begin{array}{c}\mathrm{OC} \\
(\mathrm{g} / \mathrm{Kg})\end{array}$} & \multicolumn{2}{|c|}{$\begin{array}{c}\mathrm{CaCO} 3 \\
\text { (percent) }\end{array}$} \\
\hline & & & Range & Mean & Range & Mean & Range & Mean & Range & Mean \\
\hline 1 & Rajasingamangalam & 27 & $\begin{array}{c}6.78- \\
8.48\end{array}$ & 7.84 & $\begin{array}{c}0.10- \\
0.37\end{array}$ & 0.20 & $1.7-3.9$ & 2.5 & $\begin{array}{l}0.94- \\
11.14\end{array}$ & 7.61 \\
\hline 2 & Nainarkoil & 18 & $\begin{array}{l}7.28- \\
8.44 \\
\end{array}$ & 7.97 & $\begin{array}{l}0.14- \\
0.34 \\
\end{array}$ & 0.26 & $1.9-4.1$ & 2.7 & $\begin{array}{l}3.14- \\
12.54 \\
\end{array}$ & 8.95 \\
\hline 3 & Bogalur & 12 & $\begin{array}{c}8.08- \\
8.49\end{array}$ & 8.28 & $\begin{array}{l}0.16- \\
0.32\end{array}$ & 0.23 & $1.9-3.4$ & 2.6 & $\begin{array}{l}10.41- \\
12.72\end{array}$ & 11.46 \\
\hline 4 & Paramakudi & 32 & $\begin{array}{l}7.12- \\
8.74\end{array}$ & 8.24 & $\begin{array}{l}0.12- \\
0.42 \\
\end{array}$ & 0.23 & $1.5-2.9$ & 2.2 & $\begin{array}{l}1.13- \\
12.50\end{array}$ & 11.30 \\
\hline 5 & Ramanathapuram & 11 & $\begin{array}{c}6.94- \\
8.44\end{array}$ & 7.76 & $\begin{array}{l}0.12- \\
0.26\end{array}$ & 0.18 & $1.4-3.1$ & 2.3 & $\begin{array}{l}2.56- \\
11.98\end{array}$ & 8.10 \\
\hline 6 & Tiruppullani & 5 & $\begin{array}{c}7.68- \\
8.34 \\
\end{array}$ & 8.01 & $\begin{array}{l}0.18- \\
0.42 \\
\end{array}$ & 0.27 & $2.1-3.2$ & 2.6 & $\begin{array}{c}10.24- \\
11.21 \\
\end{array}$ & 10.65 \\
\hline 7 & Mudukulathur & 26 & $\begin{array}{l}7.14- \\
8.41\end{array}$ & 7.81 & $\begin{array}{l}0.12- \\
0.32\end{array}$ & 0.22 & $2.1-3.1$ & 2.5 & $\begin{array}{l}2.13- \\
12.50\end{array}$ & 7.69 \\
\hline 8 & Kamudi & 4 & $\begin{array}{l}8.28- \\
8.44 \\
\end{array}$ & 8.37 & $\begin{array}{c}0.20- \\
0.38 \\
\end{array}$ & 0.26 & $2.6-3.9$ & 3.1 & $\begin{array}{l}10.54- \\
11.78 \\
\end{array}$ & 11.01 \\
\hline 9 & Kadadi & 19 & $\begin{array}{c}6.93- \\
8.34 \\
\end{array}$ & 7.78 & $\begin{array}{l}0.12- \\
0.26\end{array}$ & 0.18 & $1.4-2.9$ & 2.3 & $\begin{array}{l}2.25- \\
12.13 \\
\end{array}$ & 8.79 \\
\hline 10 & Thiruvadanai & 26 & $\begin{array}{c}6.98- \\
8.54 \\
\end{array}$ & 7.80 & $\begin{array}{l}0.12- \\
0.42\end{array}$ & 0.22 & $1.8-4.2$ & 2.8 & $\begin{array}{l}1.50- \\
12.25 \\
\end{array}$ & 7.29 \\
\hline 11 & Mandapam & 3 & $\begin{array}{c}6.88- \\
8.14 \\
\end{array}$ & 7.60 & $\begin{array}{c}0.18- \\
0.38 \\
\end{array}$ & 0.28 & $1.7-3.7$ & 2.5 & $\begin{array}{c}2.25- \\
4.75 \\
\end{array}$ & 3.38 \\
\hline & District & 183 & $\begin{array}{c}6.78- \\
8.74\end{array}$ & 7.96 & $\begin{array}{c}0.10- \\
0.42\end{array}$ & 0.23 & $1.4-4.2$ & 2.5 & $\begin{array}{l}0.94- \\
12.54\end{array}$ & 8.96 \\
\hline
\end{tabular}


Table.2 Micronutrient and sulphur availability in rainfed rice growing soils in different blocks of Ramanathapuram district $(\mathrm{n}=183)$

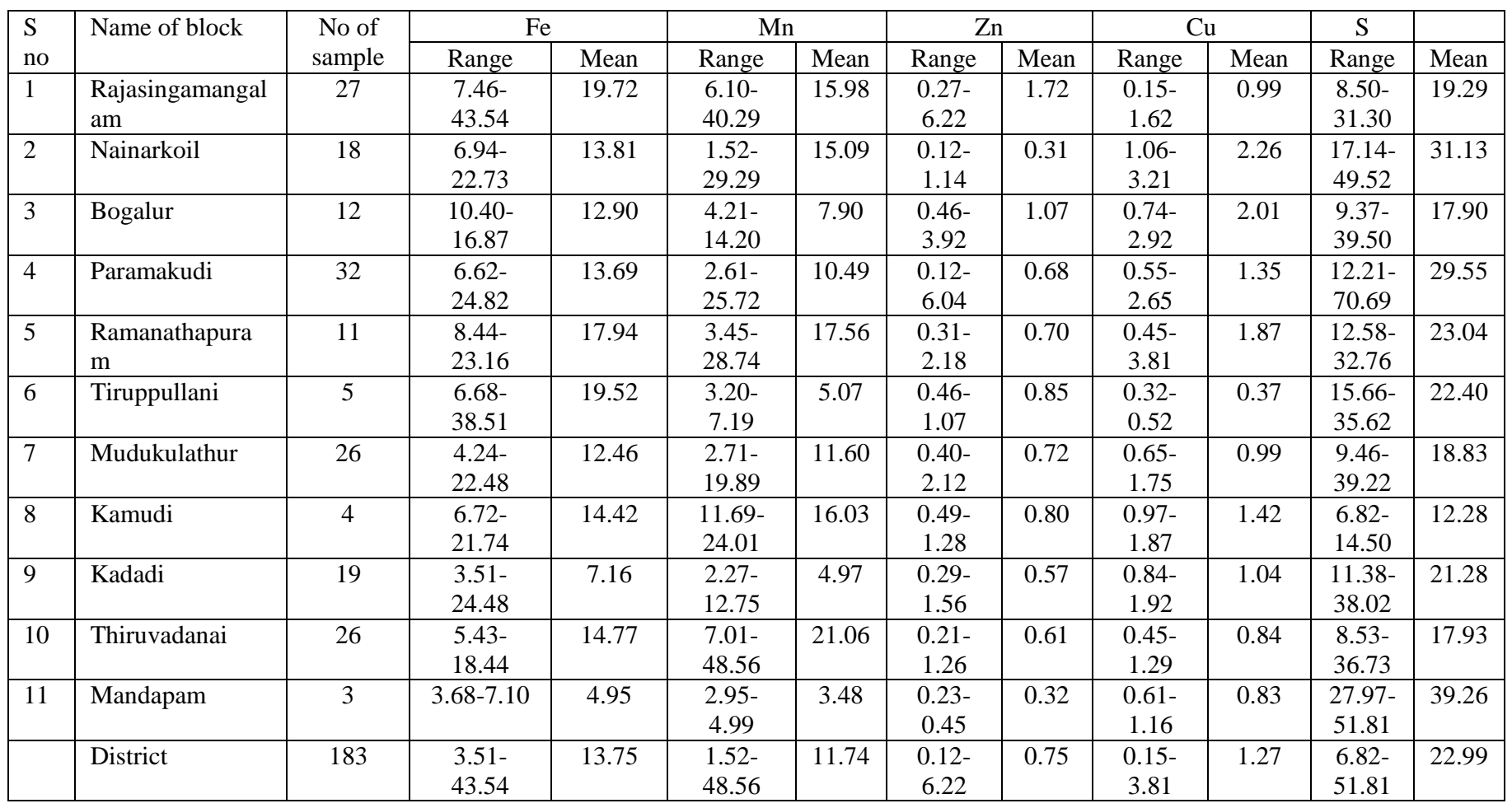

Table.3 Soil properties of rainfed chillies growing soils in different blocks of Ramanathapuram district $(\mathrm{n}=224)$

\begin{tabular}{|c|c|c|c|c|c|c|c|c|c|c|}
\hline \multirow{2}{*}{$\begin{array}{l}\text { S. } \\
\text { No }\end{array}$} & \multirow[t]{2}{*}{ Name of the block } & \multirow{2}{*}{$\begin{array}{c}\text { No. of } \\
\text { Samples }\end{array}$} & \multicolumn{2}{|c|}{$\mathrm{pH}$} & \multicolumn{2}{|c|}{$\mathrm{EC}(\mathrm{ds} / \mathrm{m})$} & \multicolumn{2}{|c|}{$\mathrm{OC}(\mathrm{g} / \mathrm{Kg})$} & \multicolumn{2}{|c|}{$\mathrm{CaCO} 3$ (per cent) } \\
\hline & & & Range & Mea & Range & Mean & Range & Mean & Range & Mean \\
\hline 1 & Rajasingamangalam & 12 & $\begin{array}{l}7.29- \\
8.41\end{array}$ & 8.02 & $\begin{array}{c}0.04- \\
0.31\end{array}$ & 0.18 & $1.7-4.1$ & 2.6 & $\begin{array}{l}1.31- \\
10.78 \\
\end{array}$ & 8.25 \\
\hline 2 & Nainarkoil & 12 & $\begin{array}{l}7.18- \\
8.32 \\
\end{array}$ & 7.97 & $\begin{array}{c}0.15- \\
0.39 \\
\end{array}$ & 0.27 & $1.7-4.2$ & 2.7 & $\begin{array}{l}2.94- \\
11.59 \\
\end{array}$ & 7.64 \\
\hline 3 & Bogalur & 19 & $\begin{array}{l}7.14- \\
8.48\end{array}$ & 8.18 & $\begin{array}{l}0.12- \\
0.32\end{array}$ & 0.21 & $1.4-3.1$ & 2.2 & $\begin{array}{l}1.18- \\
12.48\end{array}$ & 10.73 \\
\hline 4 & Paramakudi & 27 & $\begin{array}{l}7.14- \\
8.54\end{array}$ & 8.16 & $\begin{array}{l}0.11- \\
0.46\end{array}$ & 0.25 & $1.5-3.5$ & 2.3 & $\begin{array}{l}1.25- \\
12.38\end{array}$ & 10.73 \\
\hline 5 & Ramanathapuram & 5 & $\begin{array}{c}6.94- \\
8.31\end{array}$ & 7.84 & $\begin{array}{c}0.08- \\
0.52\end{array}$ & 0.25 & $1.4-3.7$ & 2.4 & $\begin{array}{l}5.21- \\
11.78\end{array}$ & 9.85 \\
\hline 6 & Tiruppullani & 5 & $\begin{array}{c}7.59- \\
8.2 \\
\end{array}$ & 7.95 & $\begin{array}{c}0.12- \\
0.61 \\
\end{array}$ & 0.40 & $2.2-3.9$ & 3.0 & $\begin{array}{l}5.64- \\
10.98 \\
\end{array}$ & 9.72 \\
\hline 7 & Mudukulathur & 35 & $\begin{array}{l}6.86- \\
8.46\end{array}$ & 8.11 & $\begin{array}{l}0.16- \\
0.34-\end{array}$ & 0.23 & $2.0-3.2$ & 2.5 & $\begin{array}{l}2.12- \\
12.37\end{array}$ & 10.38 \\
\hline 8 & Kamudi & 77 & $\begin{array}{l}6.78- \\
8.68 \\
\end{array}$ & 8.06 & $\begin{array}{c}0.04- \\
0.48 \\
\end{array}$ & 0.20 & $1.3-4.8$ & 2.7 & $\begin{array}{l}1.78- \\
11.44 \\
\end{array}$ & 9.37 \\
\hline 9 & Kadadi & 13 & $\begin{array}{l}6.82- \\
8.41 \\
\end{array}$ & 7.41 & $\begin{array}{l}0.11- \\
0.28\end{array}$ & 0.20 & $1.5-2.8$ & 2.2 & $\begin{array}{l}1.12- \\
12.51 \\
\end{array}$ & 6.53 \\
\hline 10 & Thiruvadanai & 1 & $\begin{array}{l}8.14- \\
8.14 \\
\end{array}$ & 8.14 & $\begin{array}{c}0.14- \\
0.14 \\
\end{array}$ & 0.14 & 2.1 & 2.1 & $\begin{array}{c}10.50- \\
10.50 \\
\end{array}$ & 10.50 \\
\hline 11 & Mandapam & 18 & $\begin{array}{c}6.74- \\
8.34\end{array}$ & 7.49 & $\begin{array}{l}0.11- \\
0.63\end{array}$ & 0.26 & $1.4-4.4$ & 2.7 & $\begin{array}{l}2.38- \\
12.75\end{array}$ & 6.27 \\
\hline & District & 224 & $\begin{array}{c}6.74- \\
8.14\end{array}$ & 7.93 & $\begin{array}{c}0.04- \\
0.63\end{array}$ & 0.23 & $1.3-4.8$ & 2.4 & $\begin{array}{l}1.12- \\
12.48\end{array}$ & 9.08 \\
\hline
\end{tabular}


Table.4 Micronutrient and sulphur availability in rainfed chillies growing soils in different blocks of Ramanathapuram district $(n=224)$

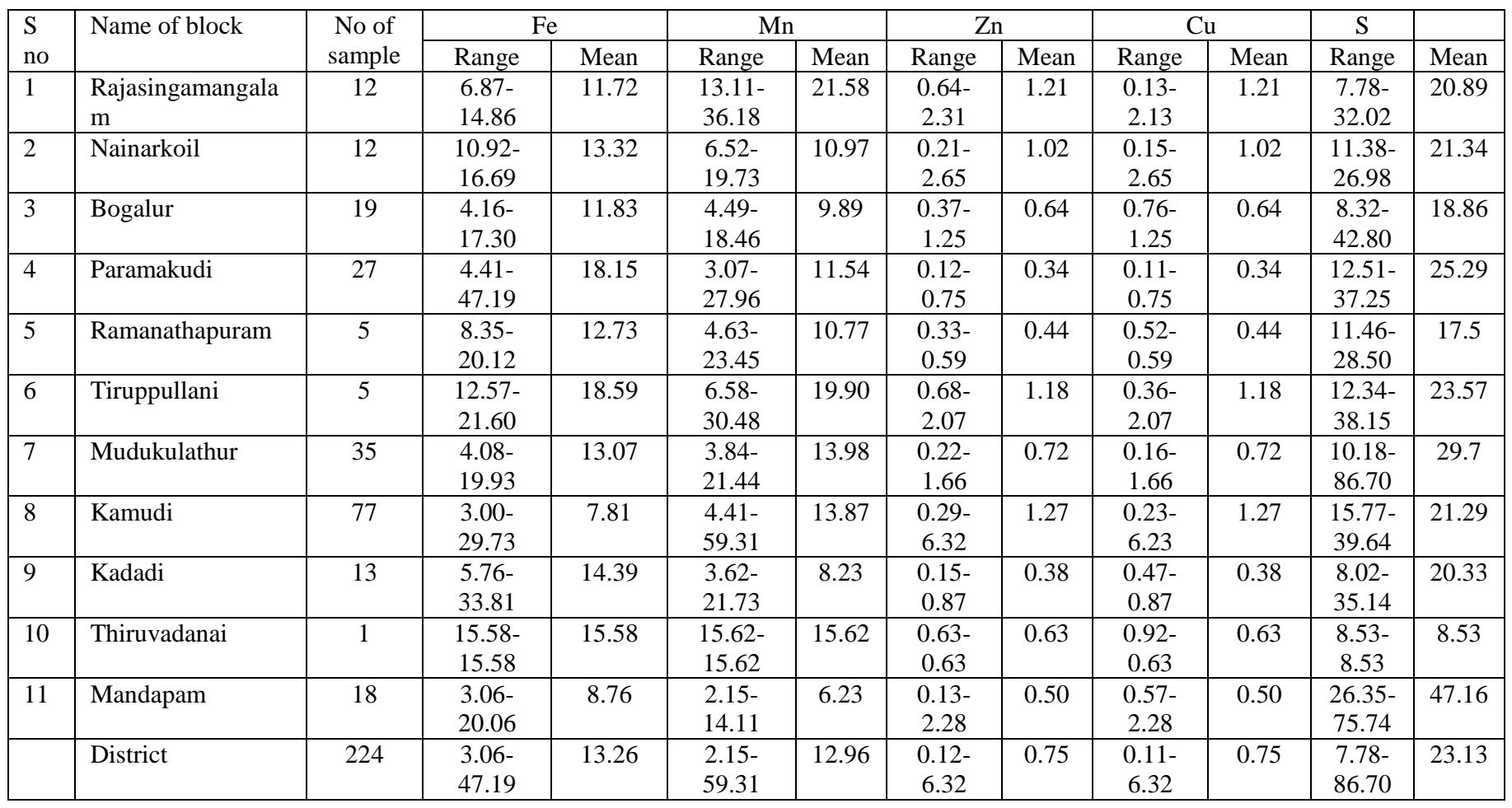

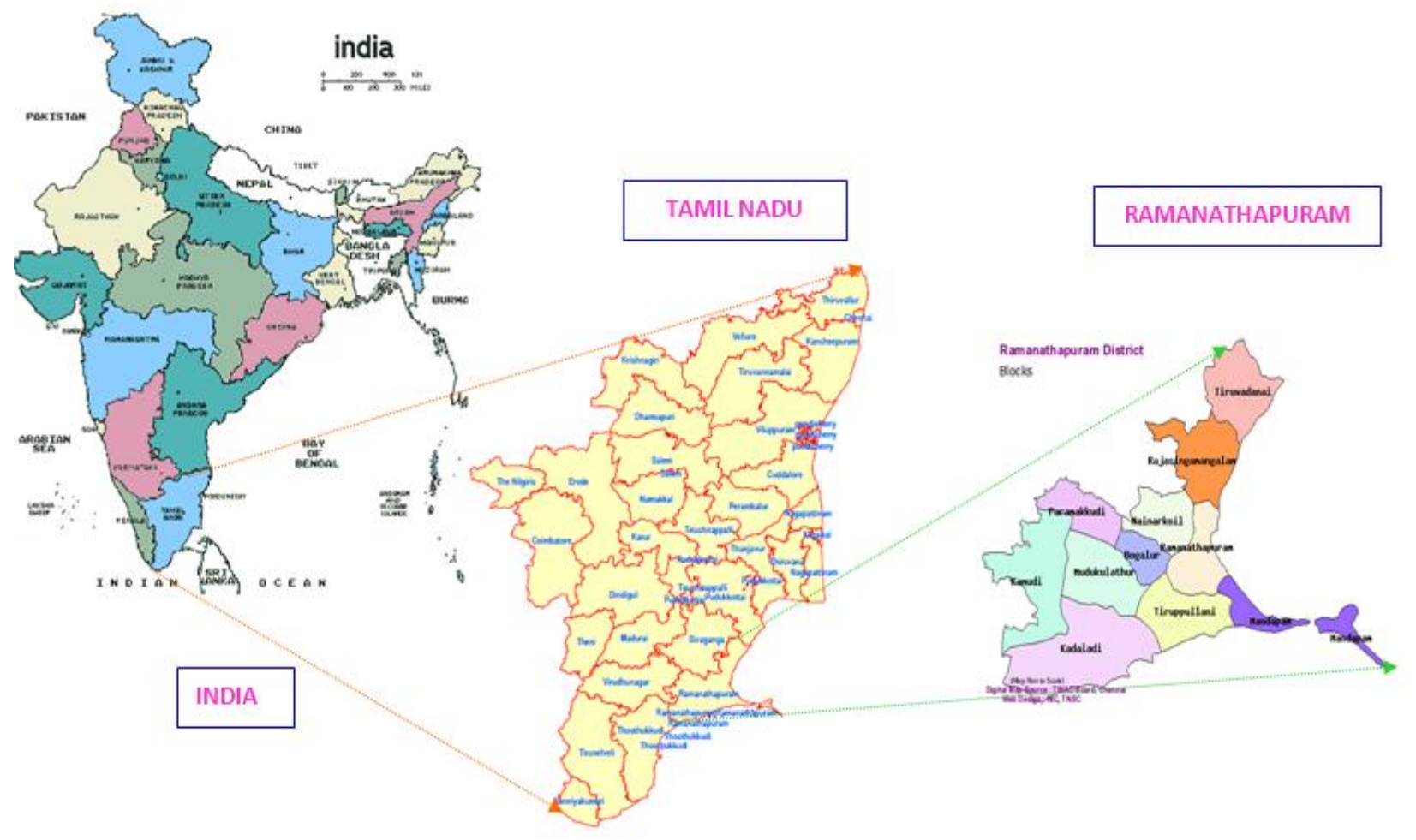


The organic content in the soils ranged from 0.13 to 0.48 with a mean of 0.24 per cent indicating that the soils were mostly low in organic carbon status (Table 3). All the rainfed chillies growing blocks were found to contain low in organic carbon content. All the soils were falls under non to moderately in calcareous nature and values varied from 1.12 to 12.48 per cent with the mean of 9.08 (Table 3). Part of the soils under all the rainfed chillies growing blocks fall under moderately calcareous nature and the mean free $\mathrm{CaCO}_{3}$ value revealed that the blocks soils of Bogalur, Paramakudi, Mudukulathur and Thiruadanai were showed the high $\mathrm{CaCO}_{3}$ value of $>10.0$ per cent.

The available sulphur content in the rainfed chillies growing soils of Ramanathapuram district ranged from 7.78 to $86.70 \mathrm{mg} \mathrm{kg}^{-1}$ with a mean of $23.13 \mathrm{mg} \mathrm{kg}^{-1}$ indicating high in soil available sulphur status (Table 4).

The DTPA-extractable $\mathrm{Zn}$ status of the soils ranged from deficient to sufficient in availability (0.12 to 6.32) with a mean of 0.75 $\mathrm{mg} \mathrm{kg}^{-1}$ (Table 4). Almost all the block soils were deficient in $\mathrm{Zn}$ status except in Rajasingamangalam and Kamudi. Low Zn status noticed in the soils of Paramakudi (0.12 $\mathrm{mg} \mathrm{kg}{ }^{-1}$ ) while the highest $\mathrm{Zn}$ observed in Kamudi (6.32 $\mathrm{mg} \mathrm{kg}^{-1}$ ) blocks (Table 4).

The available Fe content in the rainfed chillies growing soils of Ramanathapuram district ranged from 3.00 to $47.19 \mathrm{mg} \mathrm{kg}^{-1}$ with a mean of $13.26 \mathrm{mg} \mathrm{kg}^{-1}$ (Table 4). The average mean values indicated that chillies grown soils of all the blocks were observed that sufficient in DTPA-Fe status. The highest mean available $\mathrm{Fe}$ status noticed in soil samples Tirupullani (18.59 $\mathrm{mg} \mathrm{kg}^{-1}$ ) block while the lowest in Kamudi (7.81 $\mathrm{mg} \mathrm{kg}^{-1}$ ) block. Deficient to sufficient $\mathrm{Cu}$ status $(0.11$ to $\left.6.32 \mathrm{mg} \mathrm{kg}^{-1}\right)$ with a mean of $0.75 \mathrm{mg} \mathrm{kg}^{-1}$ noticed in rainfed chillies soils (Table 4).
Soil properties and nutrient availability varied with crops and cropping system. A slight increase in soil $\mathrm{pH}$ and salinity was noted in chillies growing soils than rice grown soils. The increase in $\mathrm{pH}$ of soils could be due to increased calcium carbonate content which produces more $\mathrm{OH}$ ions upon hydrolysis and created an alkaline effect (Verma et al., 2007). The soils under rainfed chillies showed deficient $\mathrm{Zn}$ status. But the very low organic carbon content of the soils indicates that corrective measures would be required to avoid $\mathrm{Zn}$ deficiency in near future and similar observations have been made by Katyal and Datta (2004) and Sood et al., (2009). The $\mathrm{Cu}$ availability in sole crop of rice was might be due to increase in finer fractions of the soil leads to increased surface area for ion exchange thus contributing to higher $\mathrm{Cu}$ availability. Deficient $\mathrm{Cu}$ availability was specifically recorded in the soils under chillies based cropping systems could be ascribed to the low organic content in the soils (Sood et al., 2009). Hence to conclude, that the soils of rice cultivation possessed the highest amount of available sulphur and micronutrients than chilly crops grown in the Ramanathapuram district. Among the cultivation of chilies and rice crops under rainfed condition, the chillies crop registered the highest amount of mean free $\mathrm{CaCO}_{3}$, available sulphur and $\mathrm{Mn}$ as compared to rice system which registered the highest amount of available $\mathrm{Fe}, \mathrm{Zn}, \mathrm{Cu}, \mathrm{B}$ and organic carbon. Similarly the mean nutrient content of sulphur, available micronutrients and all other soil properties were higher in rice based cropping system than chillies based cropping system.

\section{References}

Datta, M., and Ram, M. 1989 Status of micronutrients in some soil series of Tripura. Journal of the Indian Society of Soil Science41, 776-777. 
Katyal, J.C., and Datta, S.P. 2004 Role of micronutrients in ensuring the optimum use of macronutrients. Paper presented at IFA International symposium on micronutrients, held at New Delhi, India during Februrary 23-25.

Katyal, J.C., and Rattan, R.K. 2003. Secondary and micronutrients research gaps and future needs. Fertilizer News 48, 9-14.

Lindsay, N.L., and Norvell, W.A. 1978. Development of DTPA soil test for zinc, iron, manganese and copper. Soil Science Society of America, 42, 421428.

Paramasivam, P., and Gopalswamy, A. 1994. Distribution of micronutrients in Lower Bhavani Project (LBP) command area soil profiles. Madras Agricultural Journal81, 545-547.

Ponnamperuma, F.N., 1972. The chemistry of submerged soils. Advances in Agronomy 24, 29-96.

Rattan, R.K., Patel K.P., Manjaiah K.M. and Datta S.P. 2009. Micronutrients in soil, plant, animal and human health. Journal of the Indian Society of Soil Science 47 (4), 546-558.

Rego, T.J., Sahrawat, K.L. Wani, S.P. Pardhasaradhi, G. 2007. Widespread deficiencies of sulphur, boron and zinc in dryland soils of the Indian semi-arid tropical soils: on farm crop responses. Journal of Plant Nutrition30, 15691583.

Sharma, J.C., and Chaudhary, S.K 2007.
Vertical distribution of micronutrient cations in relation to soil characteristics in lower Shiwaliks of Solan district in North-West Himalayas. Journal of the Indian Society of Soil Science55, 40-44.

Singh, K., 2009. The critical zinc deficiency levels in Indian soils and cereal crops. In: Proc.of the International Plant Nutritional Colloquium.XVI. Dept.of Plant Sciences, UC Davis.

Somasundaram, J., Singh, R. K., Paraldiyal, A. R. and Prasad, S. N. 2009. Micronutrient status of soils under different land use systems in Chambal ravines. Journal of the Indian Society of Soil Science57 (3), 307-312.

Sood, A., Sharma, P.K. Tur, N.S. and Nayyar, V.K. 2009. Micronutrient status and their spatial variability in soils of Muktsar District of Punjab- A GIS approach. Journal of the Indian Society of Soil Science, 57(3), 300-306.

Venkatesh, M. S., Majumdar, B., Kumar, K. and Patiram 2003. Status of micronutrient cations under various land use systems of Meghalaya. Journal of Indian Society of Soil Science 51, 6064.

Verma, V.K., Setia, P.K., Shrama, P.K., Khurana, M.P.S. and Kang, G.S. 2007. Pedospheric distribution of micronutrient cation sin soils developed on various landforms in North- east Punjab. Journal of the Indian Society of Soil Science55 (4), 515-520.

\section{How to cite this article:}

Aswathy, S. Nair, S. Thyigeshwari and Muthumanickam, D. 2017. Effect of Crops and Cropping Systems on Sulphur and Micronutrient Availability of Geo Referenced Soils of Ramanathapuram District in Tamil Nadu. Int.J.Curr.Microbiol.App.Sci. 6(10): 2631-2637. doi: https://doi.org/10.20546/ijcmas.2017.610.310 